\title{
IMPACT OF THE MACRO ENVIRONMENT ON THE ECOTOURISM INFRASTRUCTURE
}

\author{
Liudmyla Bezuhla ${ }^{1}$
}

\begin{abstract}
The purpose of the study is to assess the impact of the macro environment on ecotourism infrastructure. Methodology. The theoretical and methodological basis of the article is the basic provisions of the theory of ecotourism development in the conditions of transformational changes. To achieve the goal of the research, there were used general scientific theoretical methods: generalization, explanation, grouping - to analyze the views of economists on the object of study and to formulate conclusions of the content analysis of primary sources; analysis and synthesis - to substantiate the conceptual provisions, principles in solving research problems. Results. Ecotourism infrastructure plays a key role in the development of ecotourism. Its existence is associated with the state of productive forces and the territorial division of labor, as well as the efficiency of material production. The infrastructural arrangement of ecotourism, on the one hand, depends on the pace of modernization, and on the other hand, it acts as a driver of economic growth of ecotourism. The development of ecotourism infrastructure depends on the specifics of the industry and regions and is carried out in accordance with changes in the production sphere. It is given that infrastructure has a significant impact on the efficiency of economic entities through the participation of industrial and social services in the creation of consumer value and prices of services. Thus, it is important to study the impact of the macro environment on ecotourism infrastructure. Practical implications. The subject of research is the theoretical and methodological, as well as scientific and practical principles of assessing the impact of the macro environment on ecotourism infrastructure. In the article, the principles of effective ecotourism with optimal ecotourism infrastructure usage have been justified. It is determined that the development of ecotourism can cause a variety of consequences at the local, regional and national levels, the range of which is from very favorable to destructive. Socio-economic aspects related to the development of ecotourism infrastructure are analyzed. Value/ originality. PEST-analysis of the impact of the macro environment on the ecotourism infrastructure was conducted. Having studied the impact of macroeconomic indicators on ecotourism infrastructure, it can be argued that it is optimal to put economic benefits in the foreground and ensure the preservation of their own habitat.
\end{abstract}

Key words: ecotourism, ecology, socio-economic effects, economic development, PEST-analysis, ecological risk.

JEL Classification: N50, O11, Q57

\section{Introduction}

Recently, due to the widespread implementation of the international concept of sustainable development, the role of environmentally sustainable tourism is growing. Ecotourism is essentially designed to protect and preserve nature, giving tourists all its attractions. This is its significant difference from other types of tourism, which on the contrary mainly harm the environment. More rational and careful use of natural, cultural and historical monuments will avoid or minimize the negative consequences of the functioning of the tourism industry. The purpose of the article is to assess the impact of the macro environment on ecotourism infrastructure.

\section{Literature review}

Raul Gouvea (2004) writes that ecotourism offers a unique balance between environmental protection, economic growth and development. In addition, ecotourism strategies should pay attention to: a) economic development; b) environmental protection; c) cultural protection; d) social development and, e) political development.

Solly Matshonisa Seeletse (2015) argues that ecotourism is a tourist practice associated with

Corresponding author:

${ }^{1}$ Dnipro State Agrarian and Economic University, Ukraine.

E-mail:milabezugla@gmail.com

ORCID: https://orcid.org/0000-0002-6520-4325 
visiting delicate, original and moderately untouched natural areas, which is conceived as niche tourism. Ecotourism classically includes trips to places where flora, fauna, and cultural heritage are the main attractions. Ecotourism is a perfect prospect for economic strengthening of local communities.

To develop sustainable ecotourism attractions, the government, through its regulatory and incentive solutions, must develop measures and policies to ensure the desired practices and compensate for the negative practices that occur in ecotourism.

\section{Principles of effective ecotourism with optimal use of ecotourism infrastructure}

For a more detailed disclosure of the research topic, we will analyze the criteria of environmental friendliness of the tour. Can ecotourism be mass, or is it an elite type of recreation? Ecotourism was traditionally opposed to mass tourism and was defined as limited and, to some extent, exclusive nature tourism. However, based on the modern concept of ecotourism, this is not always justified. If we limit ourselves to such a narrow definition, the economic and environmental impact of tourism in many cases is insignificant. In particular, participants in bird watching tours can be guided by the best environmental intentions. But if only a few come during the season, it will not provide a serious economic alternative to deforestation, expansion of agricultural lands and settlements. At the same time, in more "mass" types of nature tourism, provided they are well thought out, there is considerable potential. Revenues from tourism - provided that a significant part of them remains in the region create economic resources for the preservation of natural ecosystems and development of the region. Thus, in ecological terms, it is not the scale of tourism or the motivation of travelers that is really important, but the impact that their travel has. And this primarily depends on how the trip is organized. Ten visitors can do more harm than a hundred if their route is improperly planned and organized. Therefore, they can be considered ecotourists to the same extent as small groups of visitors who make complex multi-day hikes in the wild with a backpack over their shoulders and a night in tents.

It should be noted the proximity of ecological tours to forms of amateur tourism very popular in Ukraine. However, some amateur tours can be antienvironmental, in particular, a number of amateur sports tours. To have guidelines in these matters, the principles of ecotourism are highlighted (Figure 1).

The experience of foreign countries shows that the development of ecotourism can have a variety of consequences at the local, regional and national levels, the range of which is from very favorable to destructive. At each of these levels, the economic, environmental and social consequences of tourism can vary significantly depending on its scale, level of development and diversification of the local economy, cultural characteristics of the country or region. In addition, a very important point is the form and type of ecotourism that is developing in the region.

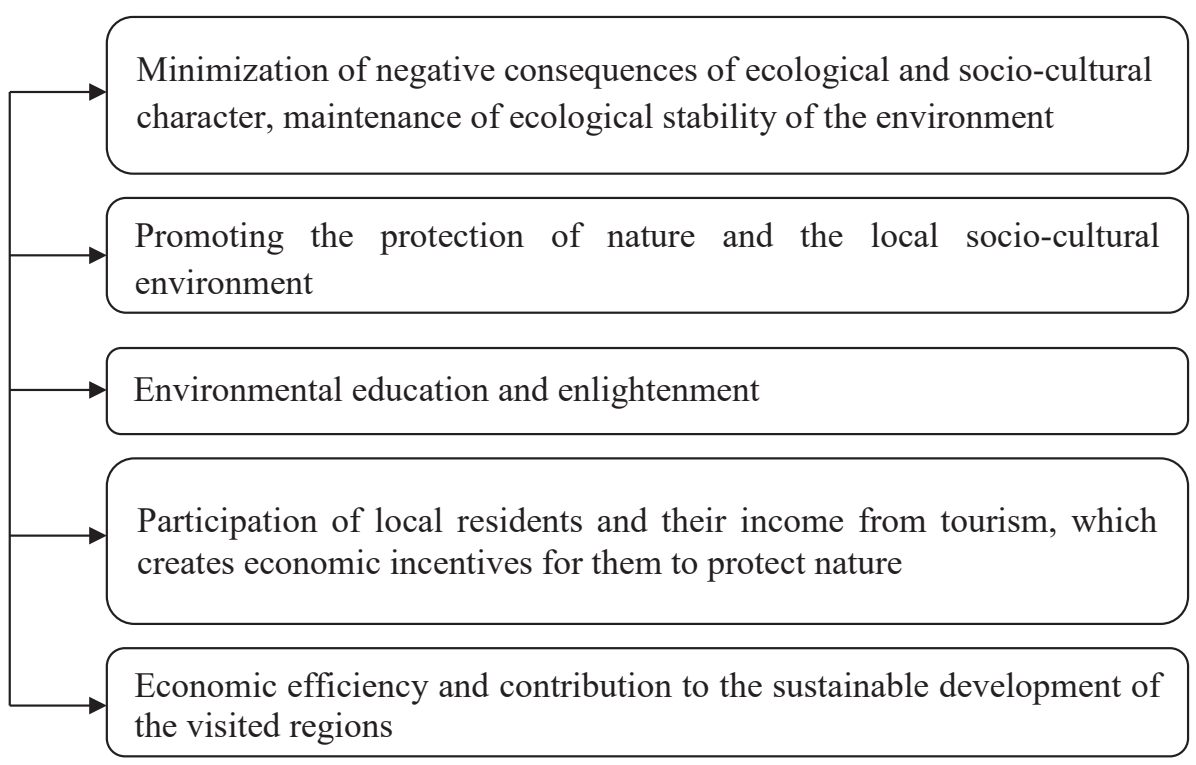

Figure 1. Principles of effective ecotourism with optimal use of ecotourism infrastructure 
Table 1

Socio-economic aspects related to the development of ecotourism infrastructure

\begin{tabular}{|l|l|}
\hline \multicolumn{1}{|c|}{ Positive impact } & \multicolumn{1}{|c|}{ Promoting the economic development of countries and regions } \\
\hline $\begin{array}{l}\text { Tourism has become an integral part of the country's } \\
\text { economy and is one of the most important sources of } \\
\text { currency for it. }\end{array}$ & Tourism is a sphere of economy subject to crises. \\
\hline $\begin{array}{l}\text { The foreign currency inflow increasing into the country. } \\
\text { The effects of the multiplier }\end{array}$ & $\begin{array}{l}\text { Tourist monostructures are dangerous for the host country, } \\
\text { as tourism is prone to fluctuations in demand. }\end{array}$ \\
\hline $\begin{array}{l}\text { Tourism has broad links with other areas of economic activity, } \\
\text { and thus indirectly affects job creation and income. }\end{array}$ & $\begin{array}{l}\text { Revenues from tourism in foreign currency are often reduced } \\
\text { due to the high need for imports of goods and services } \\
\text { (currency leakage, unfavorable net balance). }\end{array}$ \\
\hline $\begin{array}{l}\text { Attracting investment, expanding the services sector, } \\
\text { increasing the degree of diversification of the economy an imbalance, raising prices in the domestic market }\end{array}$ & The emergence of economic inequality \\
\hline $\begin{array}{l}\text { Development of more modern infrastructure, which is used } \\
\text { not only by tourists but also by locals. }\end{array}$ & $\begin{array}{l}\text { Tourism creates mainly low-paid, seasonal jobs that do not } \\
\text { provide opportunities for skills growth. }\end{array}$ \\
\hline
\end{tabular}

It is necessary to have a good idea of the potential positive and negative socio-economic effects that may occur in the development of ecotourism infrastructure, and take them into account when planning and managing tourism activities. In Table 1 there are listed the most important socioeconomic aspects related to the development of ecotourism infrastructure, examples of both positive and negative impacts.

The impact that tourism ultimately has on the socio-economic sphere largely depends on the multiplier effect, i.e. the degree to which primary revenues from tourism continue to circulate in the local economy and generate new revenues with each turn.

The contribution of tourism to the economic development of the region is higher the more it uses products and materials of local production, as well as local staff. Of course, this is possible provided that the economy of the visited regions is sufficiently developed to support tourists with a basic set of goods and services of local production. In other words, tourists staying in hotels owned and operated by locals, who supply mainly local products; provide more income to the local economy than those who consume mainly imported services.

In a number of countries, particularly in Ukraine, special measures are taken to withhold income in the country. The most common of these are the collection of land use tax and the introduction of a system of entrance fees and taxes from tourists, which provides benefits for local residents and organizations. In some regions, state licensing of enterprises in the areas of food, transport, trade, and excursion services has been introduced. Enterprises indirectly related to ecotourism (large hotels, transport companies, restaurants) may be subject to a tax on nature protection. A wellthought-out tax policy can increase the benefits of tourism development for the local population and the country's economy. Such programs, in which tax and other benefits are received by firms that employ locals and use goods produced in the country. The main purpose of such measures is to maintain in the regions a larger share of funds generated in tourism.

Eco-tourists are most willing to use local products and services. Thus, fans of ecotourism do not need living conditions, food and entertainment by the standards of luxury, like other groups of tourists (Ilchenko, Bezugla, 2019).

\section{The positive economic and social functions of ecotourism infrastructure development in the country}

In general, we can highlight the following about the positive economic and at the same time social functions of ecotourism infrastructure development in the country:

1. Creation of new jobs for the local population.

2. Stimulation of traditional forms of nature management, production of ecologically clean food products.

3. Increasing investment in both infrastructure and service, and in nature protection. 
4. Increasing the welfare of the local population and the development of special education aimed at acquiring tourism and environmental professions.

5. Development of local self-government.

7. Formation of development plans, taking into account the interests of local residents.

For a more detailed disclosure of the research topic, it will be conducted a PEST-analysis of the impact of the macro environment on ecotourism infrastructure. PEST-analysis is a marketing tool designed to identify political $(\mathrm{P})$, economic $(\mathrm{E})$, social $(\mathrm{S})$ and technological $(\mathrm{T})$ aspects of the environment that affect ecotourism infrastructure. The results of PEST-analysis allow to assess the external economic situation in the field of ecotourism infrastructure (Table 2).

According to the Law of Ukraine "On the basic principles (strategy) of the state environmental policy of Ukraine for the period up to 2030" there were selected the following indicators of the implementation of the state environmental policy. In Table 3 it is analyzed the dynamics of indicators for assessing the implementation of state environmental policy, which affect the ecotourism infrastructure in Ukraine.

Environmental risk analysis is often used to assess environmental impact. The intensity of the factors influencing the planned activity varies from high to medium and low, and is compared with the change of natural components under the influence (which is also expressed in certain gradations). Usually, the environmental risk increases in those areas where the impact of the greatest intensity occurs with the highest sensitivity of the environment to the effects of this impact. To compare the intensity of the impact on a natural object and the sensitivity of this object to changes under the influence of the impact, it is preferable to use matrices that take into account the specific conditions of the investment project. An example of such a matrix is shown in Figure 2.

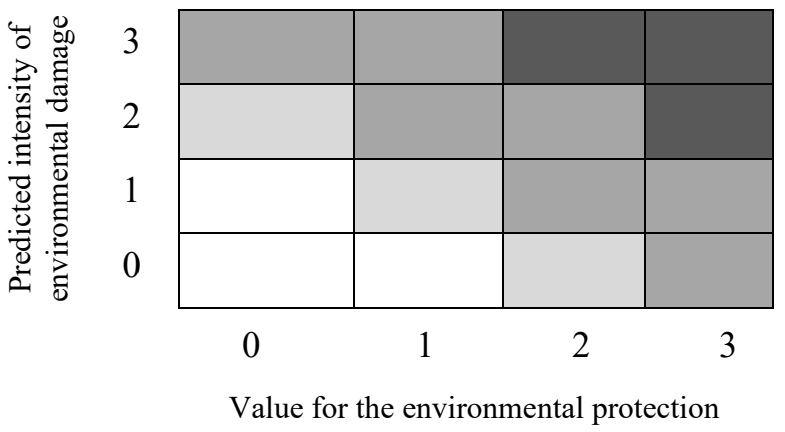

Figure 2. Matrix approach to environmental risk assessment based on comparing the value of the environmental component and the intensity of its impact

The technology of building a matrix, an example of which is shown in Figure 2, provides for the

Table 2

PEST-analysis of the impact of the macro environment on the ecotourism infrastructure

\begin{tabular}{|c|c|}
\hline $\mathrm{P}$ - political & E-economic \\
\hline $\begin{array}{l}\text { - compliance with the maximum allowable recreational loads; } \\
\text { - tourism development is carefully planned, controlled and } \\
\text { managed; } \\
\text { - compliance with the rules of conduct developed for the visited } \\
\text { natural areas; } \\
\text { - providing environmentally friendly transport used by tourists; } \\
\text { - hotels, campsites, huts where tourists stay, are located so as not } \\
\text { to violate the normal, environmentally sustainable development } \\
\text { of the surrounding landscape and do not distort its appearance; } \\
\text { - integration of ecotourism into local regional development plans } \\
\text { - close cooperation of organizations of different profiles }\end{array}$ & $\begin{array}{l}\text { - tourism provides sources of additional funding for } \\
\text { protected areas or environmental activities; } \\
\text { - participants of the tours take an active part in } \\
\text { environmental activities (volunteers, children's eco-camp); } \\
\text { - revenues from tourism are not completely withdrawn } \\
\text { from the budget, but contribute to its filling, support of } \\
\text { the local economy; } \\
\text { - careful planning, monitoring and management; } \\
\text { - a comprehensive approach to the development of } \\
\text { tourism. }\end{array}$ \\
\hline$S$ - social & $\mathrm{T}$ - technological \\
\hline $\begin{array}{l}\text { - tourists are clearly aware of their responsibility for nature } \\
\text { conservation; } \\
\text { - tours and excursions necessarily include an ecological and } \\
\text { cognitive component; } \\
\text { - tourists get acquainted with local environmental problems and } \\
\text { ways to solve them, implemented environmental projects; } \\
\text { - tourists participate in solving local environmental problems in } \\
\text { ways available to them. }\end{array}$ & $\begin{array}{l}\text { - mainly local products and labor are used; } \\
\text { - locals are involved in the tourism business and get } \\
\text { the opportunity to develop their traditional forms of } \\
\text { economy; } \\
\text { - revenues from ecotourism activities are received } \\
\text { by various social strata and groups (the principle of } \\
\text { expanding the impact), while the preservation of the } \\
\text { natural environment becomes economically beneficial for } \\
\text { the local population. }\end{array}$ \\
\hline
\end{tabular}


Table 3

Dynamics of indicators for assessing the implementation of state environmental policy that affect the ecotourism infrastructure in Ukraine

\begin{tabular}{|c|c|c|c|c|c|c|}
\hline \multirow{2}{*}{\multicolumn{2}{|c|}{ Characteristic }} & \multirow[b]{2}{*}{ Unit } & \multicolumn{4}{|c|}{ Target values } \\
\hline & & & \multirow{2}{*}{$\begin{array}{c}\begin{array}{c}\text { base year } \\
(2015)\end{array} \\
1.9\end{array}$} & \multirow{2}{*}{$\begin{array}{c}2020 \\
20\end{array}$} & \multirow{2}{*}{$\begin{array}{c}2025 \\
50\end{array}$} & \multirow{2}{*}{$\begin{array}{c}2030 \\
80\end{array}$} \\
\hline 1. & $\begin{array}{l}\text { Rural population with access to } \\
\text { improved sanitation }\end{array}$ & $\begin{array}{l}\text { percent of the total rural } \\
\text { population }\end{array}$ & & & & \\
\hline 2. & $\begin{array}{l}\text { Discharges of contaminated wastewater } \\
\text { into water bodies }\end{array}$ & percent of total discharges & 15.7 & 13 & 10 & 5 \\
\hline 3. & $\begin{array}{l}\text { River basins for which river basin } \\
\text { management plans have been approved }\end{array}$ & units & - & 1 & 9 & 9 \\
\hline 4. & $\begin{array}{l}\text { Discharges of polluted wastewater to } \\
\text { the marine environment }\end{array}$ & $\begin{array}{l}\text { percent of total discharges } \\
\text { to the marine environment }\end{array}$ & 15 & 11 & 9 & 5 \\
\hline 5. & $\begin{array}{l}\text { Massif of water with good ecological } \\
\text { condition }\end{array}$ & $\begin{array}{l}\text { percentage of total water } \\
\text { bodies }\end{array}$ & - & - & 20 & 30 \\
\hline 6. & $\begin{array}{l}\text { Volumes of use of primary raw } \\
\text { materials }\end{array}$ & $\begin{array}{l}\text { percent of total used raw } \\
\text { materials }\end{array}$ & 90 & 85 & 80 & 70 \\
\hline 7. & Area of lands of nature reserve fund & thousands of hectares & 3803.1 & 6276.9 & 7545.4 & 9095.1 \\
\hline 8. & $\begin{array}{l}\text { The area of lands of the nature reserve } \\
\text { fund of national importance }\end{array}$ & $\begin{array}{l}\text { percent of the total } \\
\text { territory of the country }\end{array}$ & 2.24 & 5.14 & 7.38 & 8.85 \\
\hline 9. & Area of lands of nature reserve fund & $\begin{array}{l}\text { percent of the total } \\
\text { territory of the country }\end{array}$ & 6.3 & 10.4 & 12.5 & 15 \\
\hline 10. & $\begin{array}{l}\text { Area of territories of the national } \\
\text { ecological network }\end{array}$ & $\begin{array}{l}\text { percent of the total } \\
\text { territory of the country }\end{array}$ & 38.2 & 39 & 40 & 41 \\
\hline 11. & Forest cover of the country & $\begin{array}{l}\text { percent of the total } \\
\text { territory of the country }\end{array}$ & 15.9 & 16 & 16.5 & 17.5 \\
\hline
\end{tabular}

gradation of the value of environmental sensitivity according to evaluation features or criteria, and the gradation of the intensity of the influence of factors. If the assessment reveals significant and unacceptable violations due to the conduct of a particular type of economic activity, then the development of appropriate measures to prevent or reduce the level of their impact. Under such conditions, it is possible to adjust the initial planned technical indicators. The next step is to reevaluate on the basis of already adjusted indicators and planned goals in the direction of preventing or reducing the level of such violations. The decision on the possibility or impossibility of implementing the next stages of the planned activity is mainly carried out according to the algorithm. It should be noted that in modern business conditions, usually, compensation for damages is made in value terms and quite rarely it takes on a natural form.

\section{Conclusions}

Thus, having studied the impact of macroeconomic indicators on ecotourism infrastructure, it can be argued that eco-tourism willcease to existas a separate area of tourism infrastructure. However, this will not happen because it will cease to be interesting or its relevance will lose its force, but because the population will understand what damage is done to nature through unreasonable activities, including tourism. Other types of tourism over time can be confidently classified as ecological. It is optimal to put economic benefits in the foreground and ensure the preservation of their own habitat.

There were highlighted the positive economic and social functions of ecotourism infrastructure development in the country: creation of new jobs for the local population; stimulation of traditional forms of nature management, production of ecologically clean food products; increasing investment in both infrastructure and service, and in nature protection; increasing the welfare of the local population and the development of special education aimed at acquiring tourism and environmental professions; development of local self-government; formation of development plans, taking into account the interests of local residents.

Ecological risks are defined as the probability of occurrence of extremely undesirable changes in ecosystems, especially related to the threat to human health, the danger of toxic pollution of the territory, 
etc. A more in-depth analysis of environmental risks involves not only determining (the probability) of its occurrence, but also assessing the losses that may be associated with it.

Negative trends that slow down the development of ecotourism infrastructure are: lack of developed infrastructure in areas suitable for ecotourism; "negative image" formed in connection with the Chernobyl disaster; lack of a single state certification in the field of ecotourism; high cost of environmentally friendly products; inadequate state environmental control in the field of construction materials production; insufficient practice of ecotourism; lack of sufficient awareness of the population about the functioning of ecotourism facilities; problems of rational economic and ecological functioning of accommodation establishments. The direction of further research is the analysis of ecological risk to assess the environmental impact of ecotourism.

\section{References:}

Awazi, W. (2002). Third World Economic Development: Tourism as a Critical Engine for Growth. The Journal of Current Research in Global Business, vol. 4, no. 5, pp. 71-81.

Ecotourism and Sustainable Development in Biosphere Reserves: Experiences and prospects. Quebec, Canada MAB/UNESCO. 2002.

EuroMAB/UNESCO Workshop on Ecotourism, Rome, Italy. 2002.

Guidelines for Community Based Ecotourism Development. UK, WWF. 2001.

Honey, M. (2008). Ecotourism and sustainable development: Who owns paradise, 2 nd edition. Washington DC: Island Press.

Kiper, T., Özdemir, G., \& Sağlam, C. (2011). Enviromental, socio-cultural and economical effects of ecotourism perceived by the local people in the Northwestern Turkey: Kıyıköy Case, Scientific Research and Essays, vol. 6(19), pp. 4009-4020.

Law of Ukraine "On the basic principles (strategy) of the state environmental policy of Ukraine for the period up to 2030". Vidomosti Verkhovnoi Rady, 2019, no. 16, p. 70.

Miller, F. (2007). Ecotourism Projects in Norway: Some Examples for Cold Climates, in Global Ecotourism Conference, Norway, 14-16 May.

Rauschelbach B., etc. (2002). Cooperating for Sustainable Tourism.

Raul Gouvea (2004). Managing the Ecotourism Industry in Latin America: Challenges and Opportunities. Problems and Perspectives in Management, 2(2), pp. 71-79.

Roxana, D. M. (2012). Considerations about ecotourism and nature-based tourism - realities and perspectives, International Journal of Academic Research in Economics and Management Sciences, vol. 1(5), pp. 215-221.

Solly Matshonisa Seeletse (2015). Local development through ecotourism in South Africa: opportunities for botanical gardens, game reserves and national parks. Environmental Economics, vol. 6 (4-1), pp. $175-179$.

Steck, D. (1999). Sustainable Tourism as a Development Option. Practical Guide for Local Planners, Developers and Decision Makers.

Ilchenko, T., \& Bezugla, L. (2019). Trends and priorities change in the european agricultural products market. Investytsii: praktyka ta dosvid, vol. 24, pp. 35-42. doi: 10.32702/2306-6814.2019.24.35 